\title{
UDK 528.73
}

\section{ŽEMĖS PAVIRŠIAUS SKENAVIMO LAZERIU IŠ ORLAIVIO TECHNOLOGIJOS ANALIŻ}

\author{
${ }^{1}$ Albinas Žalnierukas, ${ }^{2}$ Kęstutis Čypas \\ Geodezijos ir kadastro katedra, Vilniaus Gedimino technikos universitetas, \\ Sauletekio al. 11, LT-10223 Vilnius, Lietuva, \\ el.paštas:1'gi@ap.vtu.lt, ${ }^{2}$ kestutis.cypas@ap.vtu.lt
}

Iteikta 200602 05, priimta 20060921

\begin{abstract}
Santrauka. Naujas vietovès skenavimo lazeriu iš orlaivio metodas LIDAR (Light Detection and Ranging) suteikia dideles žemės paviršiaus, ypač reljefo, taip pat pastatų ir kitų objektų modeliavimo ir tyrimo galimybes. Straipsnyje pateikiamos šio metodo technologinès ypatybès, taikymo Lietuvoje galimybès ir efektyvumas. Apibūdinama aparatūra, analizuojamos paklaidų priežastys ir rezultatų tikslumas. Nustatyta, kad horizontalusis tikslumas esti apie $\pm 50 \mathrm{~cm}$, o aukščių - $\pm 10-30 \mathrm{~cm}$, skenuojant atvirą vietovę maždaug iš $1000 \mathrm{~m}$ aukščio. Lyginama su aerofotonuotraukos būdu. Teigiama, kad reljefo nuotrauka, atliekant lazerini skenavimą, ypač miškingoje ar pastatais užstatytoje vietovejje, yra tiksli ir labai efektyvi. Topografijos poreikiams skenavimą lazeriu rekomenduojama atlikti kartu su integruota skaitmenine kamera ir sudaryti ortofotografinius žemėlapius. Nurodoma, kad Lietuvoje lazerini skenavimą iš orlaivio galima efektyviai taikyti stambiujų mastelių žemėlapių, ypač miškingų plotų, reljefo nuotraukai atnaujinti, taip pat miškotvarkoje bei pastatų ir miestų 3D modeliams pagal GIS poreikius sukurti.
\end{abstract}

Reikšminiai žodžiai: topografija, skenavimas lazeriu, žemės paviršiaus modeliavimas, 3D GIS.

\section{Ivadas}

Naujai sukurtas ir pastaruoju metu geografinei informacijai apie erdvini žemès paviršių kaupti pradètas taikyti efektyvus vietovès skenavimo (zondavimo) lazeriu iš orlaivio metodas LIDAR (Light Detection and Ranging) [1, 2]. Gaunama nereguliari labai tanki taškinè trijų dimensijų žemès paviršiaus objektų išdèstymą modeliuojanti geometrine ir radiometrinè informacija. Šis metodas teikia nauju žemès paviršiaus, ypač reljefo, taip pat pastatų, mišku ir kitų objektų modeliavimo ir tyrimo galimybių. Ši metodą norima taikyti ir Lietuvoje.

LIDAR yra nauju geoinformatikos ir skaitmeninès fotogrametrijos metodų bei technologijų sudètiné dalis. Specialioje mokslinėje literatūroje yra, nors ir nedaug, o lietuviškoje visai nèra, žinių apie žemès paviršiaus skenavimą lazeriu iš oro. Straipsnyje pateikiama vietovès skenavimo lazeriu iš oro principas, skenerių tipai, nagrinejjamos vietovès sąlygos, analizuojama praktinio taikymo technologija ir rezultato tikslumas. Lyginama su aerofotonuotraukos būdu. Šio darbo tikslas - išnagrinèti LIDAR technologijos ypatumus, nustatyti gaunamą tikslumą bei metodo efektyvumą ir taikymo Lietuvoje tikslingumą.

\section{Vietovès paviršiaus skenavimas lazeriu}

Lazerinis skeneris itaisomas lèktuve arba sraigtasparnyje. Skrendant optinis elektroninis blokas generuoja lazerio impulsus ir aukštu matuojamuoju dažniu (Pulse frequency), iki 100000 impulsų per sekundę, aktyviais jutikliais matuoja atstumus iki žemès paviršiaus, medžių lajos, pastatų stogų ir kitų objektų. Impulso trukmè - 7-15 ns. Vyraujantys virpesiai dažnai esti artimieji infraraudonieji, bangos ilgis $700 \mathrm{~nm} \leq \lambda \leq 2000 \mathrm{~nm}$. Moderniujų lazerinių sistemų skenavimo dažnis - 58-83 Hz (1 pav.).

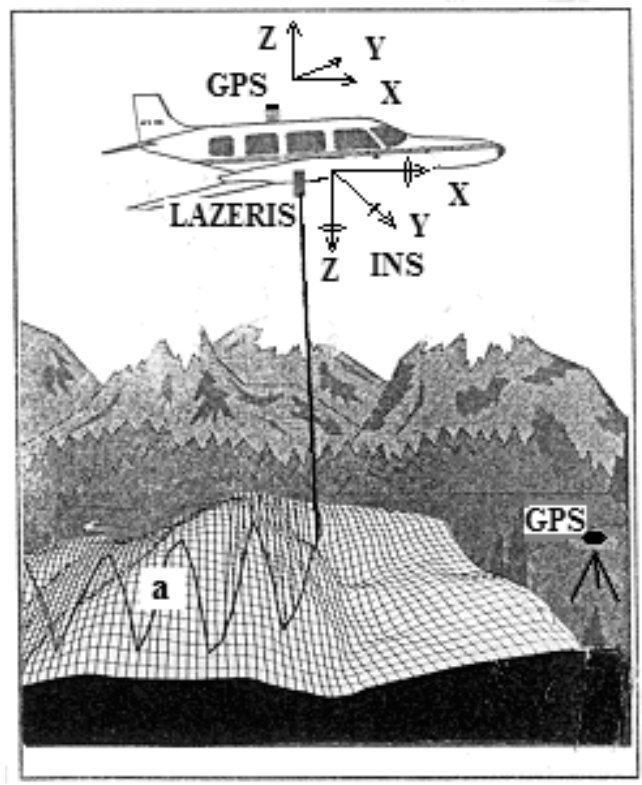

1 pav. Skenavimo lazeriu principas: a - lazerio tašku paskirstymo žemés paviršiuje pèdsakas kreipiant spinduli veidrodžiu

Fig 1. Principle of airborne laserscanning: a - the footprint of laserpoints distribution on ground by using turned mirror method 
Nuo žemès paviršiaus atspindètieji impulsai registruojami fotodiodiniu registratoriumi. Pagal impulsu išsiuntimo ir jų atspindžių registravimo laiko skirtumą nustatomas vertikalus arba nuožulnus (skrydžio kryptimi) nuotolis iki žemès paviršiaus objekto (taikinio) taškų. Esti skenerių, kurie atstumą iki žemès matuoja pagal šviesos srauto virpesių faziu skirtumus.

Iš pradžių lazeriu buvo skenuojama tik išilgai lèktuvo skrydžio (profilinis skenavimas). Neseniai sukurta skenavimo skersai skrydžio krypties metodika. Skenuojamas tam tikro pločio ištisinis ruožas, kurio plotis - apie 0,5-0,9 skrydžio aukščio. Kiekvieno ruožo kraštas dengia kito ruožo kraštą.

Skenavimo lazeriu sistema nustato erdvines polines koordinates (kampinis rastras), jų pradžią fiksuoja GPS aparatūra. Kintančiam polinių koordinačių sistemos orientavimui erdvèje XYZ ašių atžvilgiu irengta inercinè navigacinè sistema (INS) (1 pav.) [3]. Lazerinis skeneris, GPS ir INS veikia sinchroniškai, prieš skrydžio misiją nustatomi jų ekscentricitetai. Reikia bent vienos GPS referencinès stoties su žinomomis krašto koordinatėmis ir žinomu geoido aukščiu virš elipsoido (unduliacija). GPS ir INS teikia 3 tradicinius linijinius ir 3 kampinius aeronuotraukos absoliutinio orientavimo elementus.

Lazerio spindulys kraipomas veidrodiniu itaisu (Optech-System) arba taikoma sistema su lanku išdesstytų lazerio diodu eilute (laser-array) - linijinis skenavimas (pvz., Dornie-System). Skenuojant sukuriamas žemès ar kito paviršiaus trijų dimensijų lazerio tašku visumos modelis (,taškų debesis“) (2 pav.) [4]. Taškų tankis labai didelis - iki keleto, keliolikos ar kelių dešimčių tašku viename kvadratiniame paviršiaus metre. Sukaupiama šimtai disko erdvès gigabaitu informacijos.

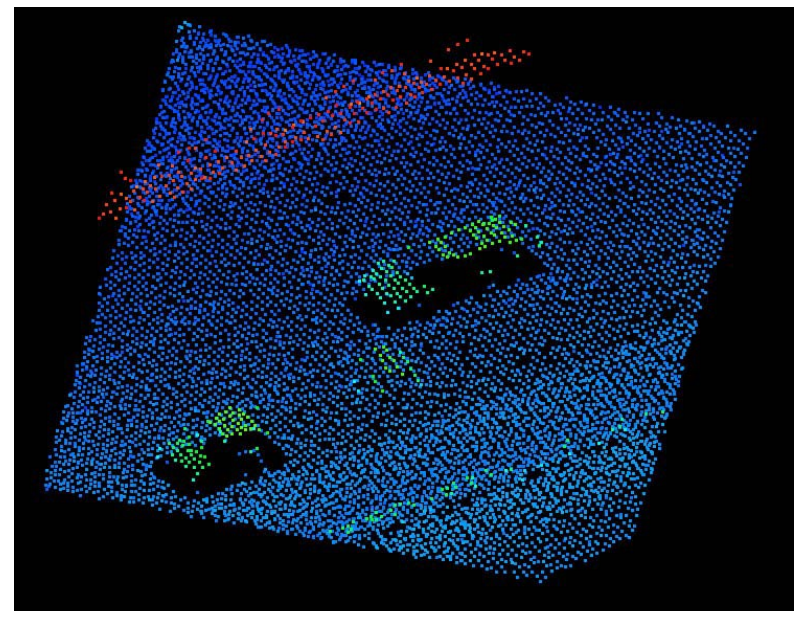

2 pav. Lazerio „taškų debesis“: automobiliai plente [4] Fig 2. Cloud of laserpoints: cars on the highway

Lazerio spindulį atspindi ne tik žemès paviršius, bet ir medžių laja, krūmai, pastatai bei kiti paviršiai (3 pav., [4]). Nustatyta, kad vidutinè lazerio spindulių skvarba iki žemès spygliuotų medžių miške esti apie $35 \%$, o lapuočiu miške vasarą apie $25 \%$, žiemą - iki $70 \%$, atitinkamai pagal medžių tankumą. Dalis impulso energijos atspindima, o kita dalis sklinda toliau spindulio kryptimi.

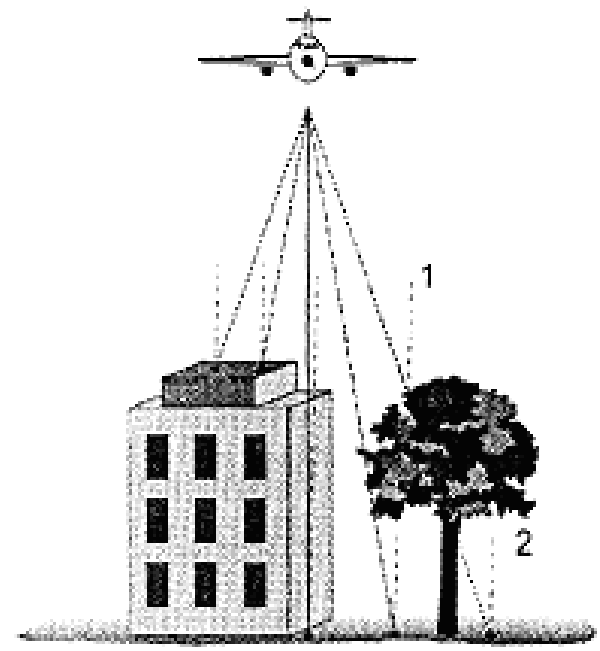

3 pav. Skenavimas lazeriu: 1 - pirmasis ir 2 - paskutinis atspindžiai

Fig 3. Laserscanning: 1 - first pulse; 2 - last pulse

Registruojami pirmojo ir paskutiniojo, o dažnai ir tarpinių (pvz., nuo medžių lapijos) atspindžių impulsai. Atspindžiai perteikia taškini tam tikro aukščio paviršiaus modelio atvaizdą. Gamtinių aplinkybių skenuojant žemès paviršių lazeriu itaka nedidelè. Galima matuoti bet kuriuo paros bei metų laiku, taip pat apniukusią dieną skrendant žemiau debesu. Trukdo migla bei rūkas (priklauso ir nuo lazerio šviesos šaltinio). Lazeris gerai skenuoja paviršius be tekstūros (šviesus betonas, smèlis, jūros pakrančiu ruožai, kartais vanduo). Pavieniai lazerio spinduliai per medžių tarpus miške pasiekia žemès paviršių ir taip galima rasti taško trimates koordinates.

Lazerinis skeneris taip pat fiksuoja nuo objektu spindulingumo priklausanti lazerio impulsų atspindžių optinio skaisčio, dažnai ir spalvini (raudonos, žalios, mèlynos), intensyvumą (multispektrinis skeneris). Taip kaupiama detali geometrinè (metrinè) ir radiometrine (semantinè) informacija apie skenuojamaji modeli. Vaizdus galima ortofotografiškai transformuoti ir jungti i mozaikas. Tik skiriamoji geba yra mažesnè negu stambiojo mastelio aerofotonuotraukų. Lazerio spindulio sklaidos pedsako žemès paviršiuje (spot) skersmuo skrendant $1000 \mathrm{~m}$ aukštyje esti apie $0,15-0,30 \mathrm{~m}$. Iprastieji skrydžiu aukščiai - 500-2000 m. Lazerio skeneriai įrengiami ir dirbtiniuose Žemès palydovuose.

\section{Lazerio skenerių tipai}

Dažniausiai naudojami puslaidininkiniai impulsiniai pavieniu atspindžiu skeneriai (Discrete return system). Šio tipo skeneriai sukuria skenuoto paviršiaus atvaizdu erdvini „taškų debesį“. Paminėtini šio tipo skeneriai: Optech-System (ALTM-1233; -1020; -3100) - bendri Kanados „Optech“ ir Vokietijos „TopScan“ kompaniju gaminiai; „Dornier-System“ (,TopoSys“, Vokietija); ALS-50 (Leica); ALS40 („LH Systems“, JAV) ir kt.

Visos atspindetosios bangos lazerio skeneriai (Full waveform laser scanner) - tai naujo tipo lazeriai. Registruojama ne pavieniai lazerio atspindžiai, o visa 
neriboto skaičiaus lazerio impulsų atspindètos (pvz., nuo žemès paviršiaus, medžių šakų, kitų objektu) koherentinès (tolydžiosios) bangos forma, sudaranti analoginę liniją, gaubiančią objektą [2] (Wagner, Ducic). Tokie yra skeneriai Riegl LMS-Q56 (Vokietija) ir ALTM3100 (modifikacija). Galima tiksliau analizuoti atspindžių taikinius bei paviršiu struktūras (1 lentelè).

1 lentelè. Kai kurių lazerio skenerių techniniai duomenys Table 1. Some laser scanners technical specifications

\begin{tabular}{|c|c|c|}
\hline $\begin{array}{l}\text { Techniniai } \\
\text { duomenys }\end{array}$ & Optech ALTM- 3100 & Dornier-System \\
\hline $\begin{array}{l}\text { Nešančiujų } \\
\text { virpesių bangos } \\
\text { ilgis }\end{array}$ & $1064 \mathrm{~nm}$ & $1540 \mathrm{~nm}$ \\
\hline $\begin{array}{l}\text { Matavimo impulsu } \\
\text { dažnis }\end{array}$ & \begin{tabular}{|l|}
$100-33 \mathrm{kHz}$ \\
(atitinkamai pagal \\
skrydžio aukšti)
\end{tabular} & $80 \mathrm{kHz}$ \\
\hline Aukštis & $80-3500 \mathrm{~m}$ & iki $1000 \mathrm{~m}$ \\
\hline Skenavimas & dinaminis impulsinis & $\begin{array}{l}\text { Statinis su stiklo } \\
\text { pluošto diodais } \\
\text { (array) }\end{array}$ \\
\hline Skenavimo dažnis & $\begin{array}{l}\text { iki } 70 \mathrm{~Hz} \\
\text { (keičiamas) }\end{array}$ & $\begin{array}{l}320 \mathrm{~Hz} \text { (kai } \\
\text { skrydžio greitis } \\
70 \mathrm{~m} / \mathrm{s} \text {, tai } \\
\text { atstumas tarp } \\
\text { eilučių } 22 \mathrm{~cm} \text { ) }\end{array}$ \\
\hline Skenavimo ruožas & $\begin{array}{l}\text { iki } \pm 25^{\circ} \\
\text { (keičiamas) }\end{array}$ & $\begin{array}{l} \pm 10^{\circ} \text { su } 255 \\
\text { matavimo taškais - } \\
\text { pikseliais } \\
(\text { atstumas tarp } \\
\text { taškų } 1,4 \mathrm{~m} \text { ) }\end{array}$ \\
\hline Registravimas & $\begin{array}{l}4 \text { atspindžiai (iskaitant } \\
\text { pirmaji ir paskutiniji); } \\
\text { atspindžių } \\
\text { intensyvumas }\end{array}$ & $\begin{array}{l}\text { Pirmasis ir } \\
\text { paskutinysis } \\
\text { atspindžiai ir jų } \\
\text { intensyvumas }\end{array}$ \\
\hline $\begin{array}{l}\text { Spindulio pèdsakas } \\
\text { (sklaida) }\end{array}$ & $\begin{array}{l}0,3 \mathrm{mrad} \text { arba } 0,8 \mathrm{mrad} \\
(30 \mathrm{~cm} \text { ir } 80 \mathrm{~cm} \\
\text { žemėje, kai aukštis } \\
1000 \mathrm{~m})\end{array}$ & \\
\hline
\end{tabular}

Lazeriniai skeneriai su integruota skaitmenine kamera (ALTM-2050) arba su videokamera (ALTM1225). Pagal skaitmeninès kameros informacija sudaromas planimetrinis vietovès modelis (pvz., ortofotografinis žemèlapis), o skenavimo lazeriu rezultatai naudojami aukščių modeliui sukurti.

\section{Technologijos ypatumai} režimu.

Daug informacijos apdorojama realiojo laiko

LIDAR, GPS ir INS duomenu sinchronizavimas. Polinès lazerinių taškų koordinatès perskaičiuojamos i WGS 84 sistemą ir pagal žinomus parametrus bei geoido aukštị virš elipsoido transformuojamos i krašto koordinačių sistemą (Lietuvoje LKS 94).

Sistemos (GPS, INS bei skenerio) kalibravimas. Laikoma, kad lèktuvo kinematinè GPS pozicionavimo paklaida dèl dreifavimo esti apie $\pm 10 \mathrm{~cm}$ (paklaida didèja ilgejjant skrydžio ruožui), o INS - $\pm 0,01$ gon, tai, esant $1000 \mathrm{~m}$ aukščiui, žemės paviršiuje sudarytu apie $\pm 16 \mathrm{~cm}$.
Siekiant eliminuoti sistemingąsias paklaidas, sistema kalibruojama sujungiant pavienių skenavimo ruožų modelius ir naudojant skersines skrydžių sekcijas, taip pat atraminius elementus. Bendras blokas formuojamas ir išlyginamas kartu su sinchronizavimo procedūromis. Atraminiai kalibravimo elementai taisyklingos geometrinès formos dideli antžeminiai ryškių ribų objektai (ilgi pramoniniai pastatai, angarai ir pan.). Šių objektų padètis tiksliai nustatoma geodeziniais metodais (dažniausiai GPS). Atliekamas šių objektų LIDAR skenavimas ir pagal atvaizdu poslinkius apskaičiuojamos sistemos kampinio orientavimo pataisos. Skenerio jutiklius reikia kalibruoti laboratorijoje.

Jungiamieji elementai. Skenuojant lazeriu būdinga tai, kad tarp gretimų ruožų modelių (,taškų debesų“) nėra identiškų taškų. Vieno ruožo lazerio taško aukšti atitinkantis gretimo ruožo modelio jungiamasis taškas randamas automatiškai interpoliuojant nusistatytojo paviršiaus, pvz., 3D trikampio, plote (4 pav.) [1]. Erdviniam $(X, Y, Z)$ modelių jungimui parenkami apibrèžtų ribų paviršiai (plokštumos) - dažnai nuožulnios stogu plokštumos su mažiausiai 4 fiksuotais taškais. Trys tokios plokštumos atstoja vieną erdvini jungiamaji tašką. Ruožų modeliai sujungiami fotogrametrijoje žinomu derinimo metodu (MATCHING) [2] (Kager). Išoriniai tinklo atraminiai elementai - tai krašto koordinačių sistemoje orientuoti pavieniai maži vietovès paviršiaus 3D modeliai arba trys taškais susietos plokštumos (trys laisvès laipsniai - vienas atraminis taškas).

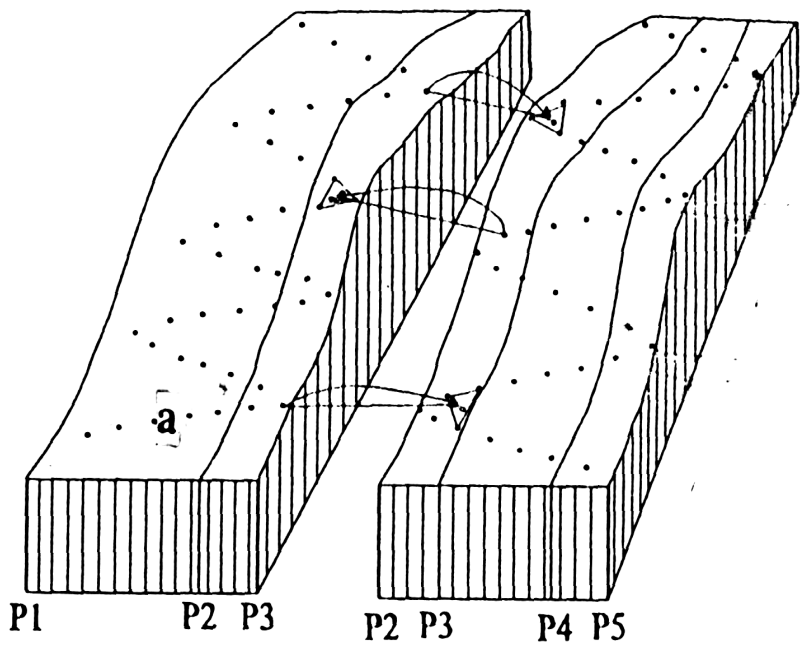

4 pav. Lazeriu skenuotų modelių aukščiu jungimas: a - lazerio taškai [1]

Fig 4. Lidar-stips of high tying: a - laserpoints

Informacijos filtravimas ir klasifikavimas. Nereikalingo tankio, aukštesnių dažnių, taip pat dèl matavimų triukšmų itakos lazerio impulsų taškai filtruojami ir klasifikuojami. Kai žemès paviršius lygus ir atviras, eliminuojama didesnè dalis registruotų taškų.

Klasifikuojant atskiriami medžių viršūnių, pastatų, žemès paviršiaus ir kitų taikinių atspindèti lazerio impulsų taškai, ir taip suformuojami objektų modeliai. 
Formuojant žemès paviršiaus modeli, automatiniu būdu eliminuojami visi ne žemès paviršiaus taškai.

Objektu modeliu vizualizavimas ir redagavimas. Monitoriaus ekrane vizualizuoto „taškų debesies“ ortogonaliojoje projekcijoje atliekami reikiami matavimai. Nereguliari aukščiu informacija interpoliuojama trikampių tinkleliais (Delaunay trianguliacija), reljefo atvaizdas gludinamas, matuojami ir redaguojami pastatų, miškų, pavienių medžių, kelių, upių, elektros tiekimo linijų 3D modeliai, kuriamas vektorinis vaizdas.

\section{Tikslumo analizè}

LIDAR lazerio spindulys nuotoli iki kieto paviršiaus išmatuoja 1-3 cm tikslumu. Tačiau vietovès skenavimo lazeriu tikslumą lemia skenerio savybès, skrydžio aukštis ir skenuojamojo ruožo plotis, skenerio pozicionavimo GPS ir orientavimo INS paklaidos, lazerio spindulių dažnis ir sklaida, atmosferos sąlygos ir ypač atspindinčiojo paviršiaus savybès bei kiti veiksniai.

Aukščiu tikslumas (Z) didelis. Prof. K. Kraus [2] vidutinèms kvadratinèms žemès reljefo modelio, sudaryto pagal lazerio taškus, absoliutinių altitudžių paklaidoms $\sigma_{h}$ apskaičiuoti rekomenduoja formulę:

$$
\sigma_{h}= \pm\left(\frac{6}{\sqrt{n}}+50 \operatorname{tg} \alpha\right) \mathrm{cm}
$$

čia $n$ - tinkamų tašku tankis, susijęs ir su skrydžio aukščiu (skaičius $1 \mathrm{~m}^{2}$ plote); $\alpha$ - žemès paviršiaus nuolydis; 6 ir 50 - empiriniai parametrai.

1 atvejis (vietovè atvira): atstumas tarp skenavimo taškų - $1 \mathrm{~m}$ arba $2 \mathrm{~m}$, taškų tankis - atitinkamai 1 ir 0,25 taško $1 \mathrm{~m}^{2}$; kai $\alpha=10 \%\left(6^{\circ}\right), \sigma_{h}= \pm 11 \mathrm{~cm}$ ir $\pm 17 \mathrm{~cm}$.

2 atvejis (miškas): vidutinis atstumas tarp lazerio taškų žemès paviršiuje - $4 \mathrm{~m}$ (skvarba - $25 \%$ ), atitinkamai $n \approx 0,0625$ taško $1 \mathrm{~m}^{2}$; kai $\alpha=10 \%$, $\sigma_{h}= \pm 29 \mathrm{~cm}$.

Horizontalusis tikslumas (X, Y) artimai siejamas su skrydžio aukščiu bei paviršių pobūdžiu ir, turimomis žiniomis, esti nuo 1/1000 iki 1/3000 šio aukščio, pvz.: skenuojant iš $1000 \mathrm{~m}$ aukščio tikètinos $0,5 \mathrm{~m}$ ir didesnès paklaidos.

Gamintojas pateikia tokias skenerių ALTM tašku altitudžių paklaidas [5]: $\sigma_{h} \leq \pm 15 \mathrm{~cm}$, kai skrydžio aukštis $1200 \mathrm{~m}, \quad \sigma_{h} \leq \pm 25 \mathrm{~cm} \quad$ ir $\quad \sigma_{h} \leq \pm 35 \mathrm{~cm}$ skenuojant atitinkamai iš 2000 ir $3000 \mathrm{~m}$ aukščių, o planimetrinès paklaidos $(1 \sigma)$ esti $1 / 3000$ skrydžio aukščio (vietovė atvira, paviršius kietas).

Iš kai kurių autorių pateikiamų empirinių duomenu matyti, kad realiomis sąlygomis lazerinio skenavimo tikslumas, ypač planimetrinis, esti mažesnis. Pavyzdžiui, H. G. Maas [6] pateikia tokias empirines vidutines kvadratines paklaidas (nuokrypius) pagal koordinačių ašis X/Y/Z: 49/41/12 cm, kai skrydžio aukštis 500 m.

K. Kraus [1] pateikia Vienos miško LIDAR nuotraukos (skrydžio aukštis $1000 \mathrm{~m}$ ) vertikaluji tikslumą $\sigma_{h}= \pm 0,50 \mathrm{~m}$. Hamburgo miesto gatvių modelių, sukurtų LIDAR metodu, aukščiu paklaidos $\sigma_{h}= \pm 10-15 \mathrm{~cm}$, o planimetrinès paklaidos $-\mathrm{iki} 0,50 \mathrm{~m}$ [7].

Apibendrinus šiuos duomenis galima teigti, kad vietovès paviršiaus modelio, sudaryto atliekant lazerini skenavimą iš orlaivio, vidutinè kvadratinè aukščiu paklaida galima 10-20 cm, o horizontalusis tikslumas 1/1000-1/2000 skrydžio aukščio. Konstatuojamas akivaizdus sisteminis efektas.

\section{Praktinio taikymo galimybès}

Topografiniu duomenu kaupimas atliekant lazerini skenavimą iš orlaivio labai efektyvus būdas. Jị taikant galima sukaupti tikslią informaciją apie reljefą net miškingu vietovių. Manoma, kad pagal skenavimo lazeriu iš orlaivio rezultatus galima sudaryti 1:2000 mastelio žemèlapi. Tačiau atviroje teritorijoje pranašumas dažnai teikiamas aerofotogrametriniams metodams [1]. Galimas ir hibridinis variantas, kai kartu naudojami LIDAR ir aerofotonuotraukos duomenys.

Skenuojant lazeriu iš oro galima automatizuotai nustatyti topografinių duomenu (ypač pastatų ir statinių) pokyčius ir įvertinti GIS duomenų bazès kokybę [8].

Dèl vandens paviršiaus veidrodinių savybių lazerio atspindžiu signalai nutrūksta. Tačiau ir ramus vanduo atspindi 1-2 \% viso impulsų skaičiaus (kai nešančiosios bangos ilgis $1,0 \mu \mathrm{m}$ ), tad to užtenka vandens lygio geodezinei altitudei nustatyti. Kai nešančiosios bangos ilgis $1,5 \mu \mathrm{m}$, vanduo visiškai absorbuoja elektromagnetinius virpesius. Lazerinis skenavimas gerai tinka upių potvyniams tirti.

Miškininkystëje taikant lazerini skenavimą iš orlaivio daroma miško inventorizacija, nustatomi medžiu biometriniai ir taksaciniai rodikliai, suformuojami medžių kupolai, apskaičiuojamas jų tankumas ir aukštis, nustatomos medžių rūšys.

Lazeriniai miško atvaizdai profiliuojami in sluoksniuojami pagal medžių aukštị ir pagal atspindžius. Žinant bandomuosiuose plotuose antžeminiu būdu nustatytus rodiklius, regresijos būdu su 7-10\% ribine paklaida apskaičiuojamas medžių kamienų storis, miško biomase ir medienos kiekis bei svoris (fitomasè).

Elektros tiekimo liniju atramos ir laidai atspindi lazerio impulsus, todèl pagal istrižų spindulių atspindžių taškus galima rekonstruoti atramų ir laidų atvaizdus, apskaičiuoti keleto centimetrų tikslumu laidų ilinkių paraboles, prognozuoti laidų būklę dèl atmosferos sąlygų.

Svarbi LIDAR taikymo sritis pastatu ir miestu modeliavimas, ypač kuriant trimates geoinformacines sistemas (3D GIS). Sukurti pusiau automatiniai ir automatiniai lazerinių duomenų analizès ir pastatų rekonstravimo metodai. Atkuriamos segmentu geometrinès struktūros, taškai, tiesès (briaunos), paviršiai ir tūriniai pastatų su stogais modeliai rekonstruojami. Ivairiu rakursu sudaromi apibendrintieji ir detalieji miestų modeliai su pavieniais medžiais.

\section{Palyginimas su aerofotogrametrijos metodais}

Paminètini tokie svarbesnieji veiksniai:

- Žemès paviršiaus bei kitų objektų (pastatu, medžių ir kt.) taškų erdvinei padéčiai LIDAR metodu 
fiksuoti užtenka 1 lazerio spindulio atspindžio, o taškui fotogrametriškai koordinuoti reikia mažiausiai dvieju spindulių iš skirtingų aerofotografavimo centrų sankirtos. Todèl taikant LIDAR skenavimą galima nesunkiai sukaupti tikslią informaciją apie medžiais, miškais apaugusios bei pastatais užstatytos vietovès reljefą ir kitu objektų aukščius, ypač kur negalima taikyti stereofotogrametrijos metodų.

- Planimetrinė vietovès nuotrauka dažnai kokybiškiau atliekama aerofotogrametriniais metodais [1 ir kt.]. Galimas ir hibridinis variantas.

- Panaudojant firmos „Terra Imaging“ (Olandija) [4] ir literatūros šaltinyje [9] (Vokietija) pateiktus duomenis, 2 lentelèje nurodomos kai kurių Europos valstybiu skaitmeninio vietovès reljefo modelio sukūrimo kainos.

2 lentelè. Reljefo skaitmeninio modelio sukūrimo kainos Table 2. Costs for digital elevation models acquisition

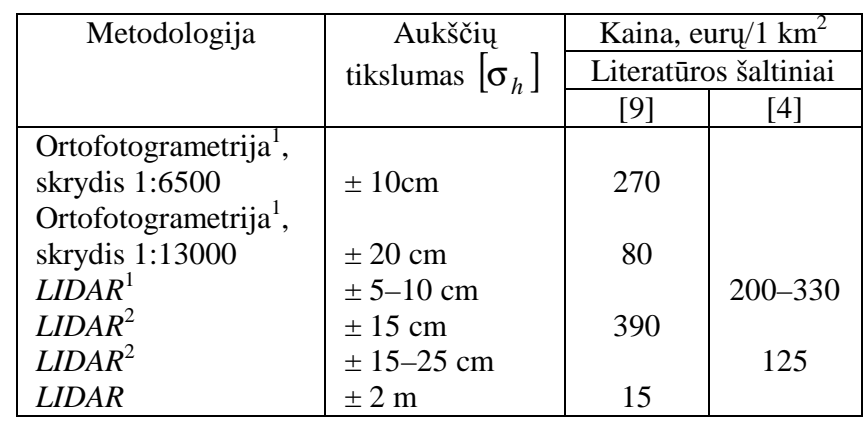

Pastabos:

${ }^{1}$ Atvira nemiškinga vietovè.

${ }^{2}$ Miškas, pastatų aukščiai, pakrantès.

- Greitas paviršiaus skaitmeninio modelio sukūrimo procesas, nors skrydžių trukmè ilgesnè nei darant aerofotonuotraukas. Lazerinio skenavimo skrydžius mažiau riboja oro sąlygos. Aerofotografijai reikia labai gerų atmosferos sąlygų (jutikliai pasyvūs).

\section{Išvados}

1. Skenavimas lazeriu iš orlaivio yra naujas efektyvus žemès paviršiaus bei objektų skaitmeninio atvaizdavimo metodas. Skenavimas lazeriu ypač veiksmingas ten, kur sunku arba negalima taikyti stereofotogrametrijos būdo (užstatyta, medžiais apaugusi teritorija, jūros pakrantė), taip pat kuriant 3D pastatų bei miestų modelius, tiriant miškų, elektros linijų, užsemtų teritorijų, augmenijos ir kitokių objektų būklę.

2. Galimybè greitai ir palyginti nebrangiai padaryti detalią miškingos teritorijos reljefo nuotrauką, formuoti miestų 3D modelius pagal GIS poreikius, atlikti kai kuriuos kitus specialius tyrimus - tai lazerinio skenavimo metodo pranašumai, palyginti su aerofotonuotraukos būdais. Tačiau planimetrinè vietovès nuotrauka aerofotogrametriniu būdu dažnai yra tikslesnè ir kokybiškesnè. Rekomenduojama tam tikrais atvejais lazerini skenavimą daryti kartu su vietovès skaitmenine aerofotonuotrauka.
3. Remiantis atlikta analize, galima teigti, kad Lietuvoje lazerini skenavimą iš orlaivio tikslinga taikyti stambiujų mastelių žemėlapių reljefo nuotraukoms atnaujinti, taip pat miškų inventorizacijai, pastatų ir miestų erdviniams modeliams kurti. Lietuvos teritorijos reljefo nuotrauka, dažniausiai mišku apaugusiose vietose, daug kur yra labai netiksli.

\section{Literatūra}

1. Kraus, K. Photogrammetrie. Band 1, Geometrische Informationen aus Photographien und Laserscanneraufnahmen. 7te Veröffentlichung. Berlin-New York: Walter de Gruyter Verlag, 2003. 516 S.

2. Kraus, K.; Wagner, W.; Kager, H.; Ducic, V. et al. Laser Scanning - Data Acquisition and Modeling. TU Vienna University Course, October 2005, p. 1-90.

3. Kilian, J.; Englich, M. Topographische Geländeerfassung mit flächenhaft abtastenden Lasersystemen. $Z$. $f$. Photogrammetrie und Fernerkundung, No 6. Karlsruhe: Verlag Wichmann, 1994, S. 207-214.

4. Van der Vegt, J. W.; Hoffmann, A. Airborne Laserscanning. Technology and Applications. LIDAR Seminar in Vilnius, March 2005. Terraimaging, p. 1-47.

5. Holter, A. Airborne Laser Scanning. Basic principles Data acquisition. Processing - Applications. LIDAR Seminar in Vilnius, March 2005. Blom, p. 1-25.

6. Maas, H. G. Planimetric and height accuracy of airborne laserscanner data: User requirements and system performance. In: Photogrammetric Week 2003. Heidelberg: Verlag Wichmann, 2003, S. 117-124.

7. Ettrich, N.; Sieh, W. Detaillierte städtische Höhenmodelle aus Laserscannerdaten zur Simulation oberflächigen Wasserabflusses. Z. f. Vermessungswesen, No 2. Stuttgart: Verlag K. Witwer, 2006. S. 53-60.

8. Vosselman, G.; Kessels, P.; Gorte, B. The utilization of airborne laser scanning for mapping. International Journal of Applied Earth Observation and Geoinformation, Vol 6, Enschede: Elsevier, 2005, p. 177-186.

9. Konecny, G. Geoinformation. Remote Sensing, Photogrammetry and Geographic Information System. London and New York: Taylor \& Francis, 2003. 248 S.

Albinas ŽALNIERUKAS. Associate Professor, Doctor.

Vilnius Gediminas Technical University, Dept of Geodesy and Cadastre. Sauletekio al. 11, LT-10223 Vilnius, Lithuania $(\mathrm{Ph}+3705273$ 5385, Fax +370 5274 4705).

A graduate of Moscow land surveying engineering institute (engineer of geodesy, 1959). Doctor (1969). Research course in Moscow (1986), training course in Norway "Fjellanger Widerøe" AO $(1995,1996)$. Author and coauthor of three text-books and 85 scientific papers.

Research interests: aerophotogrammetry.

Kęstutis ČYPAS. Doctor.

Vilnius Gediminas Technical University, Dept of Geodesy and Cadastre. Saulettekio al. 11, LT-10223 Vilnius, Lithuania $(\mathrm{Ph}+3705274$ 4703, Fax +370 5274 4705).

A graduate of Vilnius Gediminas Technical University (VGTU) (MSc, 2001). Post graduate studies at Gjøvik University College in 1998. Author of 6 publications.

Research interests: geoinformation systems, 3D modelling. 